\title{
Impacts of COVID-19 on Small-Scale Dairy Enterprises in an Indian Megacity-Insights from Greater Bengaluru
}

\author{
Md Shahin Alam (D), Eva Schlecht (D) and Marion Reichenbach *(D) \\ Animal Husbandry in the Tropics and Subtropics, University of Kassel and Georg-August-Universitaet \\ Goettingen, Steinstr. 19, 37213 Witzenhausen, Germany; shahindps@uni-kassel.de (M.S.A.); \\ eschlech@uni-kassel.de (E.S.) \\ * Correspondence: tropanimals@uni-kassel.de
}

Citation: Alam, M.S.; Schlecht, E.; Reichenbach, M. Impacts of COVID-19 on Small-Scale Dairy Enterprises in an Indian

Megacity-Insights from Greater Bengaluru. Sustainability 2022, 14 2057. https://doi.org/10.3390/ su14042057

Academic Editor: Andrea Pezzuolo

Received: 14 January 2022

Accepted: 6 February 2022

Published: 11 February 2022

Publisher's Note: MDPI stays neutral with regard to jurisdictional claims in published maps and institutional affiliations.

Copyright: (C) 2022 by the authors. Licensee MDPI, Basel, Switzerland. This article is an open access article distributed under the terms and conditions of the Creative Commons Attribution (CC BY) license (https:// creativecommons.org/licenses/by/ $4.0 /)$.

\begin{abstract}
Natural calamities and pandemics massively affect small-scale entrepreneurs. In this paper, we aim to assess how the COVID-19 pandemic affected small dairy farms in the megacity of Bengaluru, India, where they supply a high share of the milk demand. In 2020 a total of 129 farms were visited before the first lockdown (January to March) and interviewed again after the lockdown had been loosened (August to September). Questions addressed feed supply to dairy cows, milk yield and marketing, and coping strategies for lockdown impacts. Results showed that the share of farmers not feeding concentrates increased from $1 \%$ before lockdown to $7 \%$ afterward $(p<0.05)$, and those not offering dry forages increased from $20 \%$ to $33 \%(p<0.05)$ due to increasing forage prices. Milk yield dropped in all surveyed farms from $3905 \mathrm{~L}$ before to $2861 \mathrm{~L}$ after lockdown $(p<0.05)$ due to the sale of $30 \%$ of lactating cows across the farms. Enabling farmers to better cope with shocks through feed storage and by processing their surplus milk into durable products should be prioritised by supporting institutions such as dairy cooperatives. Alternatively, insurance schemes can capacitate farmers to maintain a fresh milk supply to urban consumers in the wake of global challenges.
\end{abstract}

Keywords: coping strategy; dairy production; metropolis; pandemic; smallholder; interview

\section{Introduction}

Urbanization is a major trend of the 21st century; in the next decade, this phenomenon will be strongest in Asia and West Africa, creating both opportunities and challenges [1]. On the one hand, people move into urban areas to achieve a better quality of life [2]. On the other, this puts enormous pressure on land, food production, and other natural resources in cities and their outlying neighbourhoods [3,4]. The extensive use of land for buildings, roads, and other infrastructure leaves little space for food production near cities, threatening the food security of the urban population $[4,5]$. Cities mostly depend on rural food production systems, but in the Global South, part of the food has to be produced in and around cities to fulfill the demand of city dwellers because of weaknesses in the food value chain, such as weak cool-chains [3,5]. Food production in both rural and urban areas can be threatened by natural calamities (e.g., floods, droughts, earthquakes, tsunamis, firestorms) as well asdiseases (epidemics and pandemics; [6]). Wheeler and Braun [7] estimated that by 2050 , global food production could decline by $8 \%$ due to natural calamities. Historically, pandemics like the Spanish flu (1918, [8,9]); Ebola (2013-2016, [10]); the Hong Kong flu (1968, [9]); SARS (2002-2003, [11]); and avian influenza (1997, 2005, 2009-2010, 2014, [9,11]), had far-reaching economic, social, and political consequences [12]. In 2019, the advent of the novel SARS-CoV-2 virus evolved into one of the most serious pandemics of the past 100 years [13]. The severe acute respiratory syndrome coronavirus 2 (SARS-CoV-2, colloquially known as COVID-19) was first diagnosed in Wuhan, China, in December 2019 [14]. From China, this highly contagious disease spread around the globe in a couple of months, becoming pandemic by March 2020 [15]. In many countries, a lockdown was 
imposed on the population to slow the spread of infection, strongly affecting all aspects of public and private life, industries, and the economy $[13,16]$. Pandemics also have direct and indirect effects on food production and supply chains [8] because of the strong dependency of the latter on (long-distance) transportation and the perishable nature of many food items such as milk. In consequence of the COVID-19 lockdowns, milk was dumped in the United States of America [17], Canada [18], India [19], and the United Kingdom [20], while spoilage of high quantities of milk was reported from eastern Africa [21]. In addition, a reduced demand for milk and falling milk prices were observed in Brazil [22], the United States of America [22], Bangladesh [23], Iran [24], and India [13], leading to further challenges for dairy producers.

Before the outbreak of COVID-19, the livestock sector contributed 5.1\% to India's GDP (2018-2019, [25]), providing primary income opportunities for 70 million people [26]. India produces 188 million tons of milk in a year-20\% of the global milk production-with a 6\% annual growth rate [26]. In India, the first strict COVID-19 lockdown started on 24 March 2020 and was prolonged several times until 31 May 2020. From 1 June 2020 onward, a partial lockdown was introduced, allowing essential services, industries, and farms to resume their activities $[19,27,28]$. However, the pandemic led to a $4.8 \%$ decrease in the Indian economy in 2020 and is projected to cause a further $2.8 \%$ economic loss in 2021 [29,30]. According to Chandel et al. [28], the Indian dairy sector lost approximately 9 million US dollars every day during the lockdown due to a $25-30 \%$ reduction in the demand for milk, increased milk production costs, and a falling milk price [13,19]. The effects of the COVID-19 crisis on the dairy sector, which resulted in milk dumping by protesting farmers, were covered by several Indian newspapers, online portals, blogs, and television broadcasts $[19,31,32]$. Immediately after the start of the lockdown, two scientific reports discussed the problems of a reduced consumer demand for milk, falling milk prices, and unavailability of industrial dairy feed [27,33]. Kumar et al. [13] pointed to the worsening cost-benefit ratio of dairy farming in Uttar Pradesh State. Meanwhile, Uddin et al. [23] highlighted differences in the economic loss of dairy farms according to herd size. Yet, all of these studies discussed the consequences of the lockdown rather than the strategies dairy producers used to cope with its consequences, focusing on rural dairy production systems. However, a substantial amount of milk is also produced by small-scale farmers in and around the towns, cities, and megacities of India, such as in Bengaluru, Southern India [34]. Bengaluru hosts a very active and diversified dairy production sector that mainly builds on smallholder farmers keeping two to five lactating cows [35]. Dairy producers in and around Bengaluru supply their cows with finger millet straw, Napier grass, African tall maize, wild grass, and commercial concentrate feeds. Pinto et al. [36] reported an average milk yield of $10.7 \mathrm{~L}$ per animal and day on dairy farms in and around Bengaluru. Dairy producers rely on dairy cooperatives for inputs, e.g., veterinary care and concentrate feeds, collection of their milk, and transport to a processing plant. In addition, milk is sold directly to neighbours or restaurants through middlemen [35]. Given these differences, we hypothesized that Bengaluru's dairy farmers were affected by the lockdown. We particularly aimed to understand which mitigation strategies they adopted to deal with the impacts of the COVID-19 lockdown and if the size of the dairy herd affected their choice of mitigation strategy.

\section{Materials and Methods}

\subsection{Study Area, Dairy Farmers, and Surveys}

The survey was conducted in the Greater Bengaluru region (Figure 1); Bengaluru is the capital city of the southern Indian state of Karnataka, and the city presently hosts about 10 million inhabitants [37]. Located on the Decca plateau, at 600 to $900 \mathrm{~m}$ above sea level (m a.s.l.) in the southern half and 300 to $600 \mathrm{~m}$ a.s.l. in the north, ambient temperatures at Bengaluru average $26^{\circ} \mathrm{C}$ across the year and yearly rainfall amounted to $1146 \mathrm{~mm}$ in the period 1989-2018 [38,39]. Across the city's urban, peri-urban, and rural areas, dairy farming is present and contributes to the income of the involved families [40]. The current 
number of approximately 137,000 dairy cows in the Greater Bengaluru region yield about 295,000 L of milk per year [41].
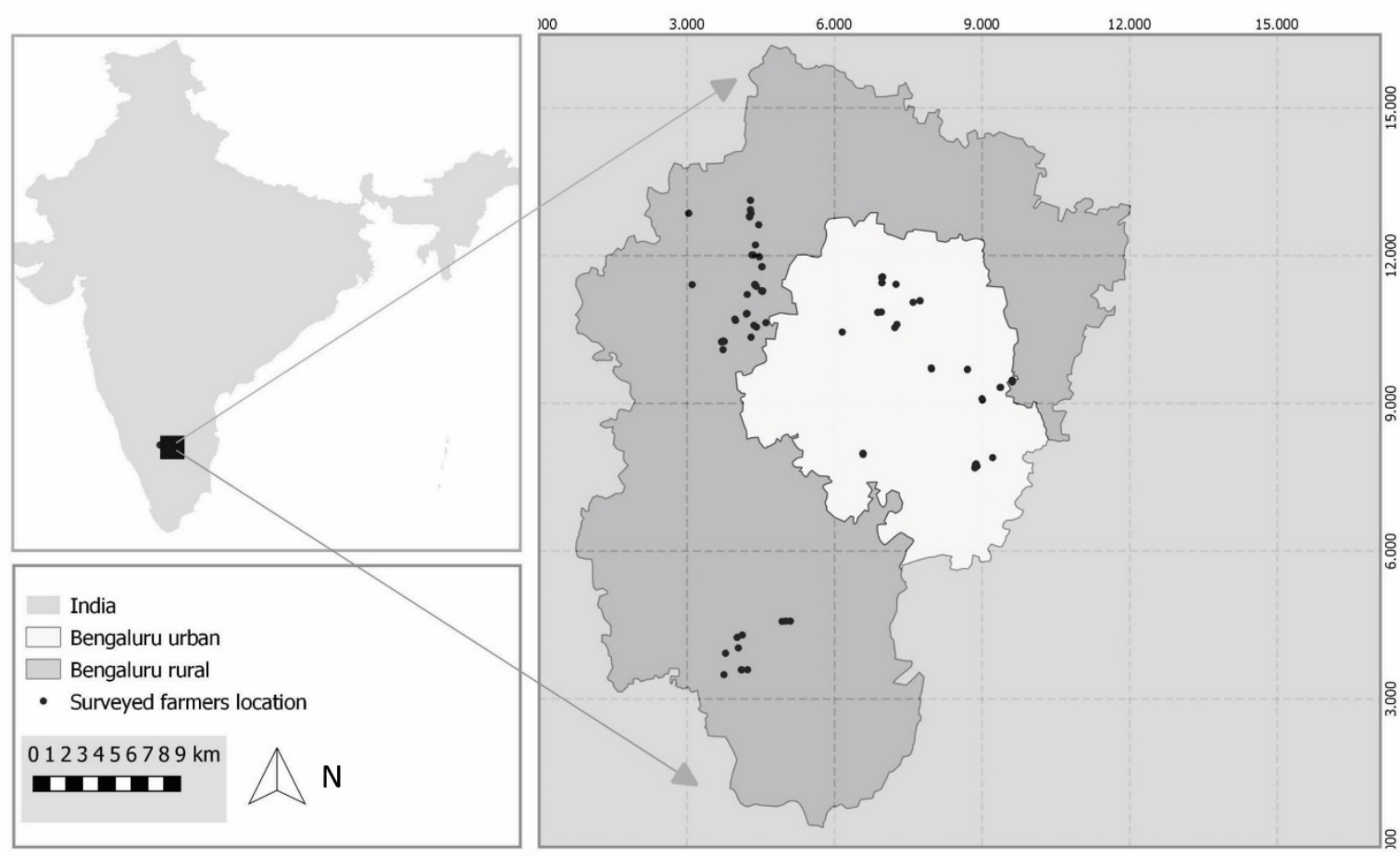

Figure 1. India (left), and the Greater Bengaluru region (right) hosting the 129 surveyed dairy farms.

We originally selected 18 lakes, where we found cattle grazing or dairy farmers harvesting fodder for their cows to study the utilisation of cattle fodder from public grounds such as lakeshores. Owners of grazing cattle were found through scouting the lake surroundings and the snowball sampling method, and 98 dairy farmers grazing their cattle or harvesting cattle feed near one of the numerous lakes of Greater Bengaluru were selected. In addition, 47 dairy farmers who did not rely on forages from lake shores were randomly selected from a previous survey [36] to act as the control group. In total, 145 dairy farmers keeping at least two lactating (L) or dry (D) cows or already inseminated heifers $(\mathrm{H})$ to guarantee a market-oriented production were asked for their oral agreement to conduct an interview and agreed. The survey participants were visited for a direct interview at their farm between 18 January and 20 March 2020 (before lockdown). The location of each farm was georeferenced with a handheld GPS device (Garmin eTrex 10, Schaffhausen, Switzerland), and a face-to-face interview was conducted with each farmer based on a structured questionnaire with open and closed questions. Just after our first interview round, a strict COVID-19 lockdown started on 24 March 2020 and was prolonged several times until 31 May 2020: vehicle movements between states and districts were completely restricted except for emergencies [42]. The government supported work from home as far as possible. All public and private organizations, hotels, restaurants, markets, and most shops closed. Only shops selling food items, milk booths, and animal fodder stores were allowed to open from 6 to 10 am [42]. Afterward, a partial lockdown was introduced from 1 June 2020 onward (Figure 2). To understand the impacts of the COVID-19 lockdown on the surveyed dairy farmers, we conducted a follow-up interview by telephone from 22 August to 12 September 2020 (after lockdown). Out of the 145 dairy farmers, 16 could not be reached again. Both interviews before and after lockdown explored aspects of cattle feed availability, feed acquisition and feeding management, milk production and milk marketing, as well as access to dairy farming inputs and services and long-term farm management plans (Appendix A). In the telephone interview, the questions were rephrased 
in such a way that the effects of the COVID-19 lockdown on the different aspects could be captured.

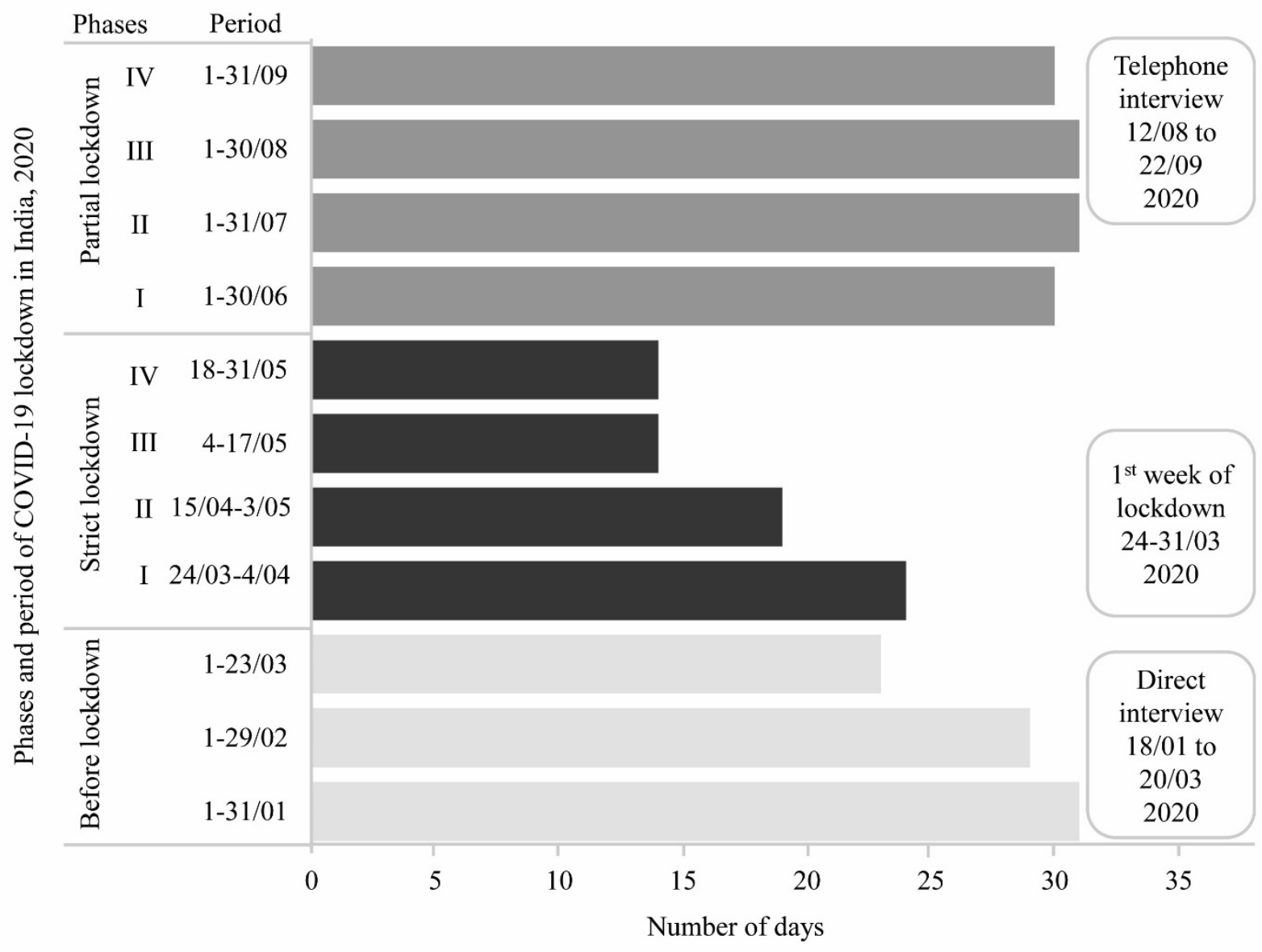

Figure 2. Phases of COVID-19 lockdown in India, 2020.

\subsection{Data Analysis}

The average number of LDH was 4.5 per farm. Based on LDH numbers, we defined threshold values for farm size as follows: the first quartile range depicts small farms $(2-3 \mathrm{LDH} ; \mathrm{n}$ surveyed dairy farms $=52)$, the second and third quartile ranges depict medium farms $(4-6 \mathrm{LDH} ; \mathrm{n}=55)$ and the fourth quartile range depicts large farms (7-10 LDH; $\mathrm{n}=23$; Table 1).

Table 1. Number (n), herd size, and milk yield of surveyed dairy farms per size category in Greater Bengaluru, India.

\begin{tabular}{|c|c|c|c|c|c|c|c|}
\hline \multirow{2}{*}{ Farm Size } & \multirow{2}{*}{$\mathbf{n}$} & \multicolumn{3}{|c|}{ Lactating, Dry Cows and Heifers (n) } & \multicolumn{3}{|c|}{ Milk Yield (L/d) } \\
\hline & & Total & Mean & SD & Total & Mean & SD \\
\hline Small & 52 & 138 & 2.7 & 0.5 & 381 & 7.3 & 3.9 \\
\hline Medium & 54 & 252 & 4.8 & 0.8 & 491 & 9.1 & 3.3 \\
\hline Large & 23 & 184 & 8.0 & 1.1 & 186 & 8.1 & 2.7 \\
\hline
\end{tabular}

SD: Standard deviation.

Data were analysed $(n=129)$ using tabulation software and open-source statistical software $\mathrm{R}$ (version 4.0.3). Descriptive statistics concerning different farm sizes and the time period before the lockdown and after lockdown establishment (independent variables) were computed by calculating frequencies and percentages for categorical, nominally scaled variables, while arithmetic mean and standard deviation $( \pm)$ were calculated for milk yield and LDH numbers. The least significant difference (LSD) test was used to determine statis- 
tical differences between periods and farm sizes, respectively, for quantitative variables; in case of differences, pairwise t-tests were computed by applying the Bonferroni correction. For categorical variables, statistical differences between farm sizes were explored by the Chi-square test. Significance was declared at $p<0.05$.

\section{Results}

\subsection{Feeding Management before and after Lockdown}

Before the lockdown, dairy farmers owned between 2 and 10 LDH cattle. Genotypes were crossbred Holstein-Friesian, Sahiwal, Sindhi, Jersey, and local breeds. The average milk yield was $8.2 \mathrm{~L} \mathrm{cow}^{-1}$ day ${ }^{-1}$. The majority $(75 \%)$ of dairy farmers sold the milk to dairy cooperatives of which they were members; the remaining $25 \%$ sold the milk directly to private consumers and restaurants. Cattle were fed with cultivated or naturally growing green forages such as Napier grass (Pennisetum purpureum S.), Alligator weed (Alternanthera philoxeroides G.), Bermuda grass (Cynodon dactylon P.), Para grass (Brachiaria mutica S.), Water hyacinth (Eichhornia crassipes S.) and mixed herbaceous species (Bermuda grass, Alligator weed, Para grass, and Vetiver (Chrysopogon zizanioides R.)), and cultivated or purchased dry forages, mainly finger millet straw. Furthermore, $99 \%$ of the dairy farmers fed concentrate feed to their animals. While $31 \%$ of the interviewed farmers harvested or purchased (green) fodder growing on lakeshores, $28 \%$ allowed their cattle to graze on lakeshores directly. Another $38 \%$ of farmers collected grass from roadsides and in designated construction areas, and $34 \%$ allowed their cattle to graze road sides or designated construction areas directly.

Due to the lockdown restrictions, $28 \%$ of the farmers changed the amount of feed offered, the ration components, and the share of different feeds. The majority ( $88 \%$ ) of farmers stated to cultivate more green grass after rather than before lockdown; hence, the lockdown did not affect the fodder supply from the dairy farmers' own land, but affected the supply of feed harvested on public land due to strict lockdown regulations. However, the lockdown affected the concentrate supply, with $7 \%$ of farmers not feeding concentrate after lockdown versus $1 \%$ not feeding concentrate before lockdown $(p<0.05$; Figure 3$)$. The lockdown also affected the availability of dry forage, with $33 \%$ of the dairy farmers having problems buying dry forage after lockdown versus $20 \%$ facing this problem before lockdown $(p<0.05)$. Grazing opportunities on lakeshores and other public land were also affected, with only $15 \%$ of the dairy farmers grazing their cattle on lakeshores after lockdown versus $28 \%$ before lockdown $(p<0.05)$.

The reasons dairy farmers gave for decreasing the use of some feedstuffs after lockdown were mostly unavailability due to lockdown restrictions and higher prices (Figure 4). The costs of cultivating grass by the dairy farmers themselves also increased due to the higher prices of inputs such as fertilizers. The harvest of green fodder on public lands, including lakeshores, was impossible as it was forbidden to leave the house. The market price of dry forage increased due to higher demand caused by the declining availability of green fodder and due to the restrictions of vehicle movements between states and districts.

\subsection{Lockdown Impacts on Herd Size, Milk Yield, and Revenue from Milk Sale}

The average dairy herd size decreased from 4.5 LDH per farm with 80\% lactating cows before lockdown to $3.8 \mathrm{LDH}$ per farm with $73 \%$ lactating cows after lockdown $(p<0.05)$. On large farms, herd size decreased from 8.0 to $5.5 \mathrm{LDH}$ and on medium ones from 4.8 to 4.2 LDH ( $p<0.05$ in both cases; Figure 5). On small farms, herd size declined from 2.6 to $2.5 \mathrm{LDH}(p>0.05)$.

Overall, $31 \%$ of the dairy farmers decreased their herd size, whereby $30 \%$ were selling off lactating cows and 5.5\% sold all of their cows. The main reasons stated for decreasing herd size, and especially for selling lactating cows, were the higher prices for inputs and lower revenue for milk, as well as the unavailability of feed during lockdown. More specifically, $28 \%$ of the interviewed farmers were facing feed shortage, $18 \%$ complained about lower milk prices and higher feed costs due to higher transportation costs and general unavailability of feed, $8 \%$ struggled with a reduced demand for their milk, 31\% faced a 
general lack of capital for farming activities, and 15\% pointed to cow health problems due to limited access to veterinary care (Figure 6).

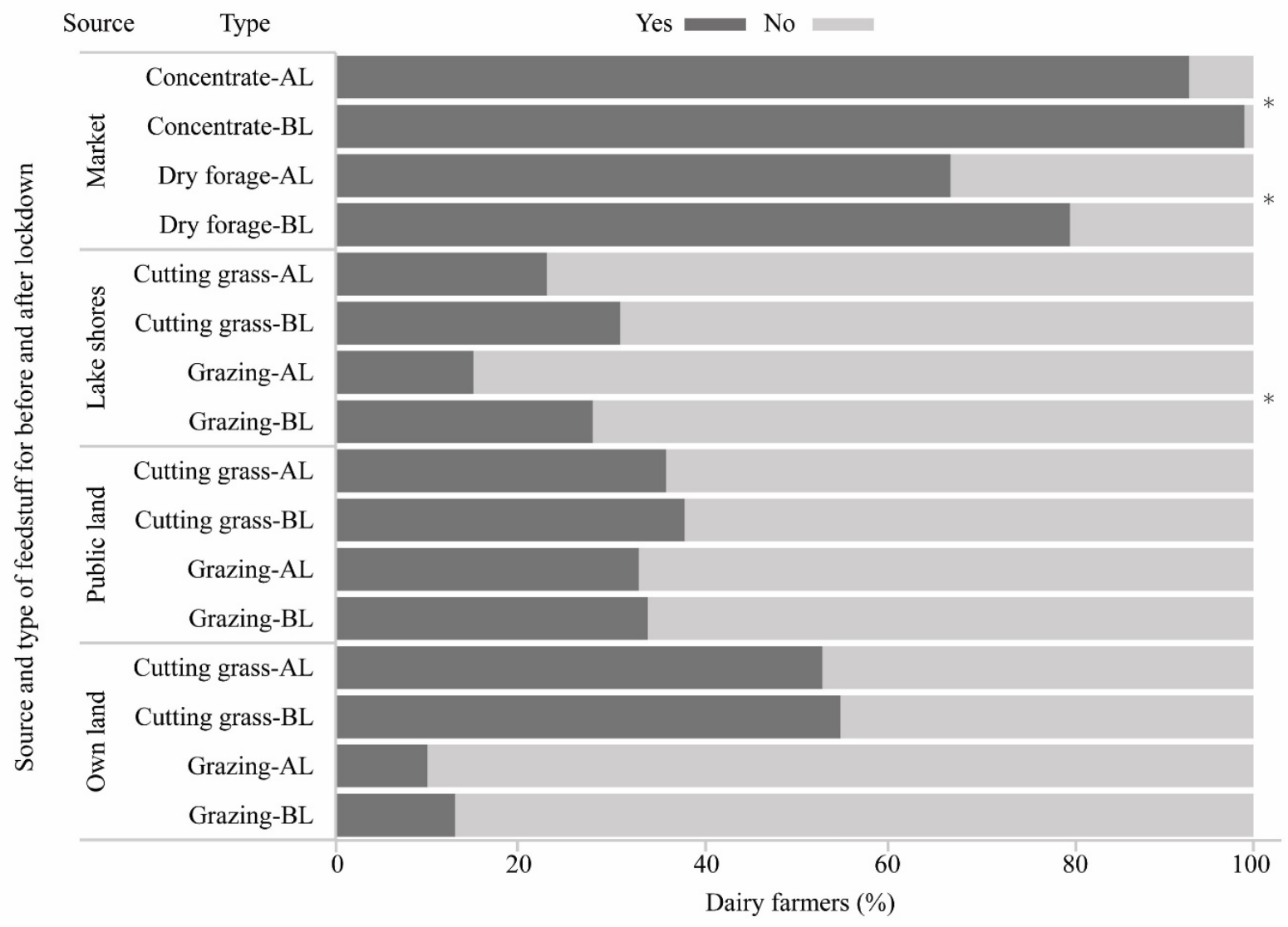

Figure 3. Use of different feedstuffs (yes/no) by dairy farmers before lockdown and after lockdown establishment in Greater Bengaluru, India. BL = before lockdown, AL = after lockdown; * Values with asterisk differ significantly at $p<0.05$.

$\begin{array}{llll}\text { Source } & \text { Type } \quad \text { High price } & \text { Unavailable } & \text { Movement restrictions }\end{array}$

$\begin{array}{ll}\stackrel{\vec{d}}{\bar{J}} & \text { Concentrate } \\ \sum & \text { Dry forage }\end{array}$

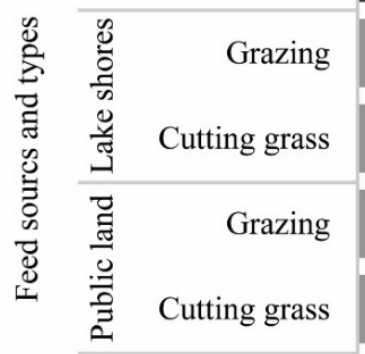
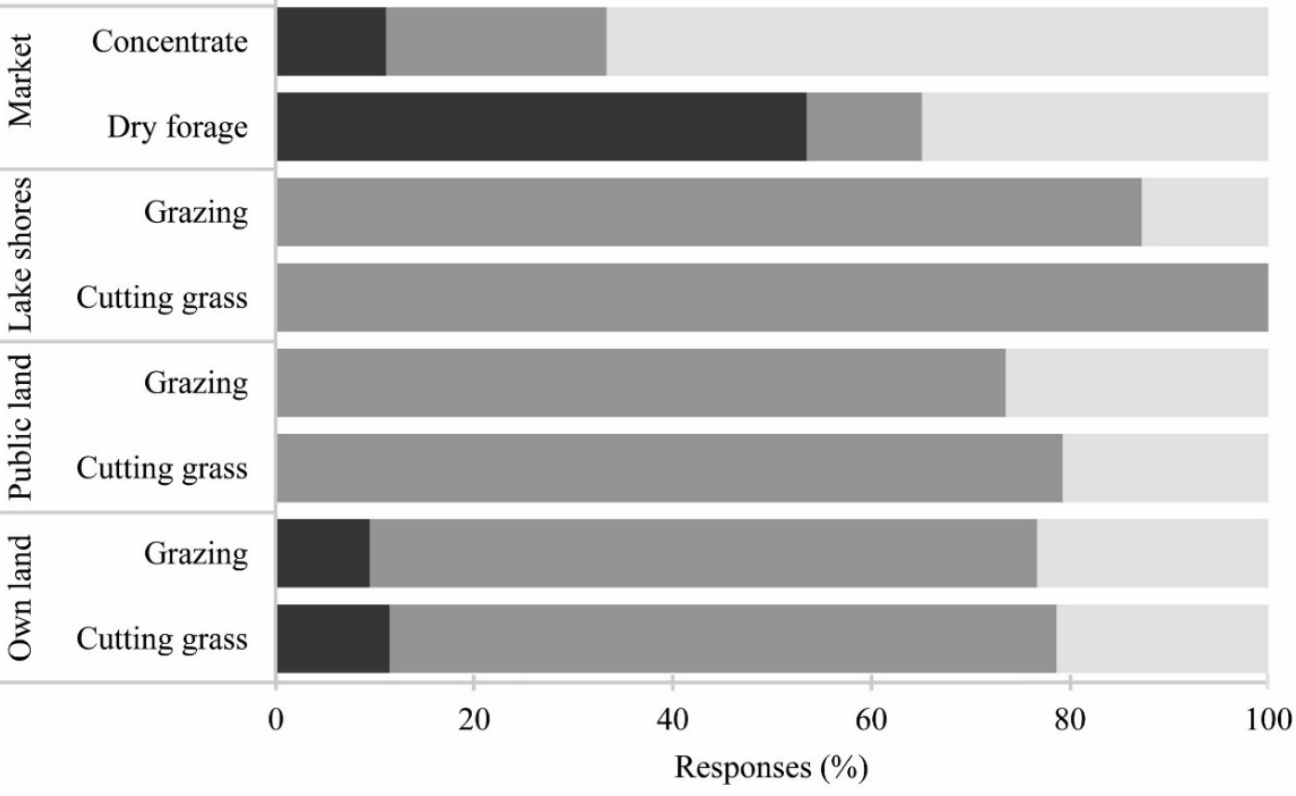

Figure 4. Reasons given by dairy farmers for not using a certain feedstuff after lockdown. 


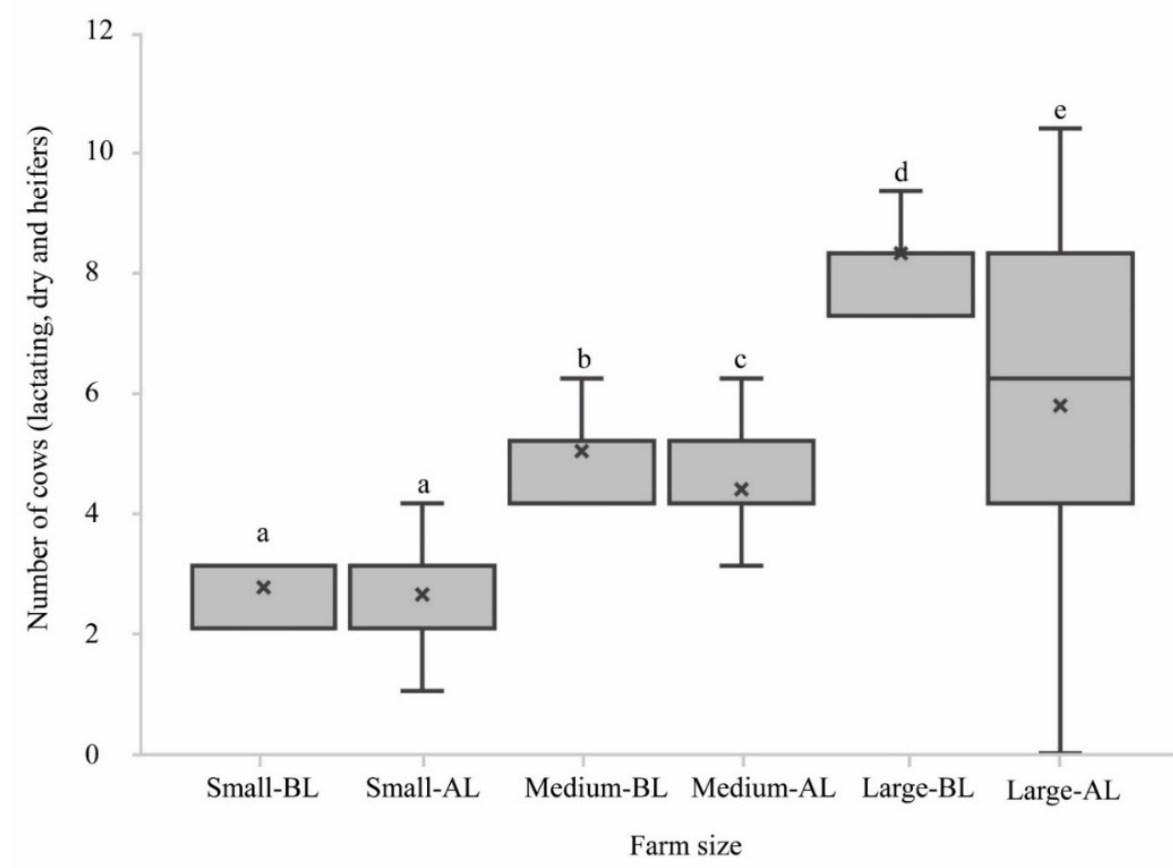

Figure 5. Number of lactating and dry cows and heifers before lockdown (BL) and after lockdown establishment (AL) on small, medium, and large dairy farms in Bengaluru. Contained in the box is the median, limits of the box indicate the 25 th and 75 th percentile, vertical lines show typical data range, and cross sign show mean values. The means of boxes with different superscript letters differ at $p<0.05$.

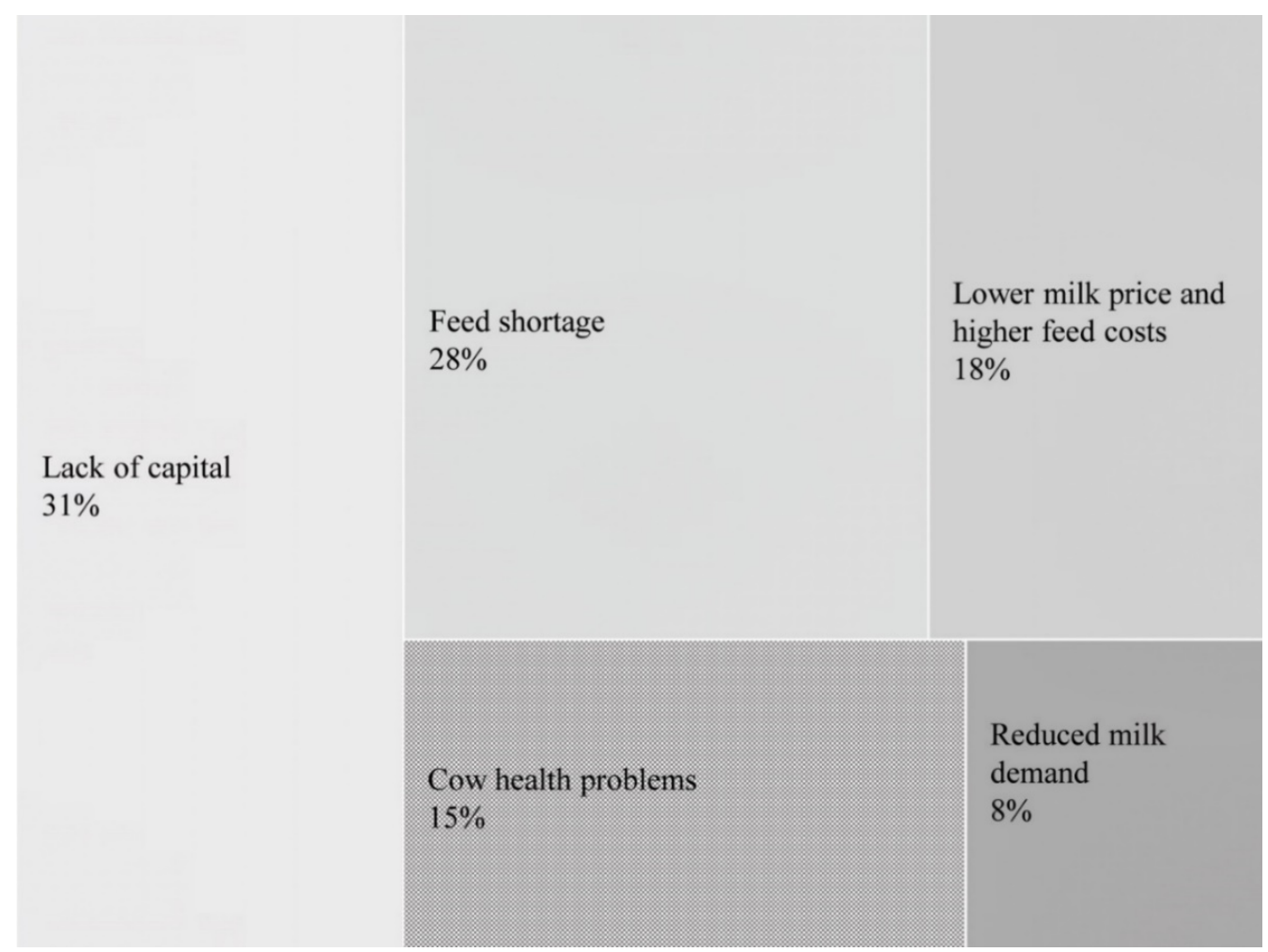

Figure 6. Reasons given by dairy farmers for decreasing herd size after lockdown in Greater Bengaluru, India.

The average milk yield per cow and day was 8.2 L before lockdown and 7.6 L after lockdown, without significant differences between farm sizes (Figure 7). Across farms, 
the overall daily milk yield was $3905 \pm 19 \mathrm{~L}$ before and $2861 \pm 16 \mathrm{~L}$ after the lockdown $(p<0.05)$. This $26 \%$ decrease was mainly explained by the decreasing number of lactating cows per herd, the explanation given by $30 \%$ of the interviewees for lower milk yield per farm. Some $(14 \%)$ dairy farmers stated that they stopped milking their lactating cows earlier than normal, and $8 \%$ related the lower feed offer to reduced milk production by their lactating cows.

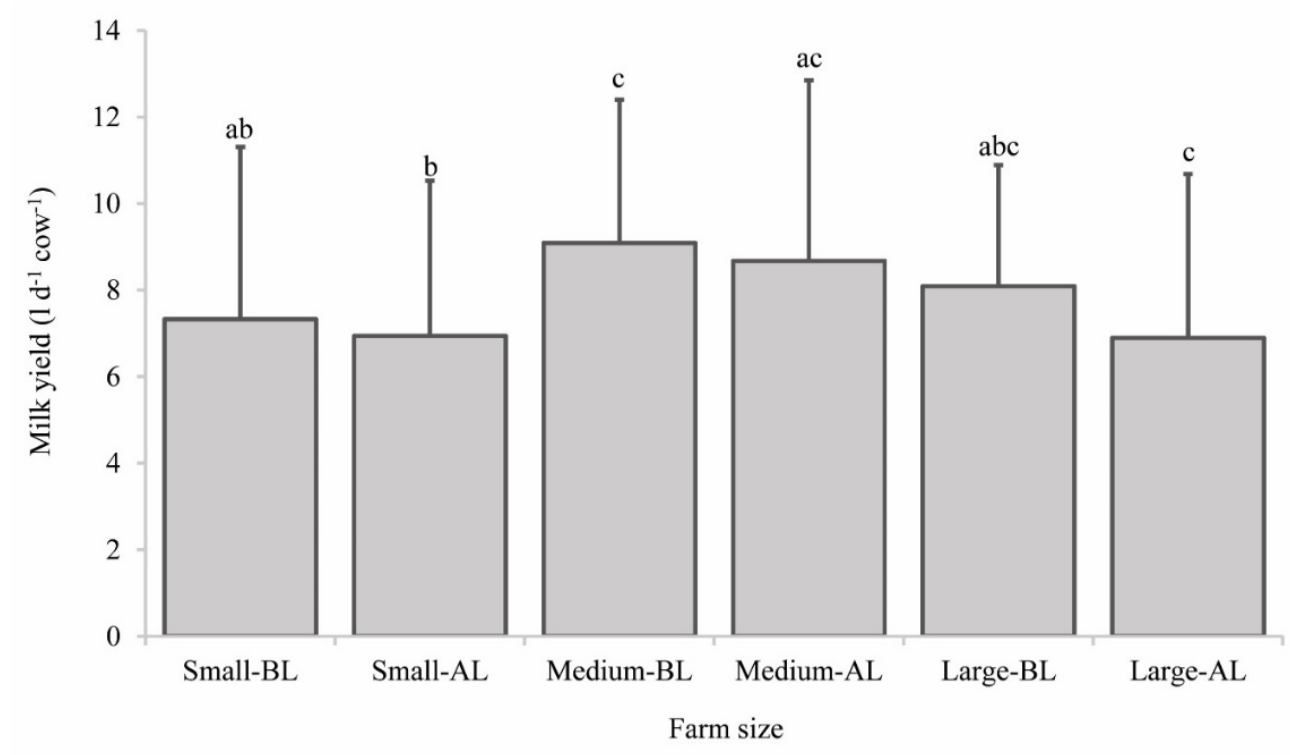

Figure 7. Milk yield (bar: mean; error bar: SD) before lockdown (BL) and after lockdown establishment (AL) on small, medium, and large dairy farms in Bengaluru. Different superscript letters indicate differences between means at $p<0.05$.

The main reason for selling lactating cows was the milk price paid by dairy cooperatives, which dropped by $12 \%$ from 27 Indian rupees (INR) before lockdown to 24 INR after lockdown $(p<0.05)$. However, the price of milk directly sold to consumers did not change. In addition, the monetary subsidy provided by dairy cooperatives to their farmers also decreased from 5 INR before to 4.5 INR per liter of milk after lockdown. Next to selling dairy cattle, dairy farmers tried to cope with these constraints by engaging in additional income-generating activities; this applied to $25 \%$ of the interviewees and a majority thereof (73\% among the $25 \%$ ) took up or expanded small ruminant farming. Consequently, the number of sheep and goats kept by the survey respondents increased by $28 \%$ and $6 \%$, respectively, after lockdown. Another $21 \%$ of the dairy farmers got more engaged in crop cultivation, or took up a job in the private sector after May 2020.

\subsection{Farmers' Perception of Lockdown Impacts and Coping Strategies}

In the first week of the lockdown (24-31 March 2020), 78\% of the surveyed dairy farmers faced problems related to their daily activities; thereof, $83 \%$ didn't have sufficient resources (money, feed, short-term milk preservation facilities) to face the shock, 13\% couldn't sell milk at this time, and 4\% didn't have enough information about the COVID-19 hygiene protocol for milk production, preservation, transportation, and selling during the lockdown (Table 2). After lockdown, fewer dairy farmers (20\%) were affected than during the 1st week of lockdown ( $78 \%$ farmers) because they had adapted to the lockdown situation by using their own financial or labour resources (savings, jewelry, land, family labour) and received financial support from family members or loans from financial institutions to carry on dairy farming. When asked what they would have done differently if they had known about the implementation of the lockdown in advance, $69 \%$ of the dairy farmers didn't have any idea, but $26 \%$ claimed that they would have stored more forage. When asked how they planned to cope with COVID-19 in the months ahead, $82 \%$ of the interviewees had no specific plans, and 18\% planned to store feed, sell cows, rear more small ruminants, 
or intensify crop cultivation. A third of the farmers (36\%) perceived the decline in milk price as the greatest challenge during the lockdown; for $31 \%$ it was the increased feed cost; and for $19 \%$ the difficulties in milk marketing due to reduced milk demand and difficulties in milk delivery to customers and the cooperatives.

Table 2. Problem perception and mitigation strategies of dairy farmers before and after different phases of lockdown in Bengaluru $(n=129)$.

\begin{tabular}{|c|c|c|}
\hline Question & Answer & Frequency $(\%)$ \\
\hline \multirow{2}{*}{ Milk marketing problems during first week of lockdown } & No & 78 \\
\hline & Yes & 22 \\
\hline \multirow{2}{*}{ Milk marketing problems after lockdown } & No & 90 \\
\hline & Yes & 10 \\
\hline \multirow{2}{*}{ Farm management problems during first week of lockdown } & No & 22 \\
\hline & Yes & 78 \\
\hline \multirow{2}{*}{ Farm management problems after lockdown } & No & 80 \\
\hline & Yes & 20 \\
\hline \multirow{2}{*}{ Reasons for decreasing impact of lockdown over time } & Adaptation of resource use & 63 \\
\hline & Support by family or bank loan & 37 \\
\hline \multirow{3}{*}{ Shock mitigation strategies before lockdown } & No idea & 69 \\
\hline & Feed storage & 26 \\
\hline & Reduction of herd size & 5 \\
\hline \multirow{4}{*}{ Shock mitigation strategies after lockdown } & No idea & 82 \\
\hline & Feed storage & 8 \\
\hline & Reduction of herd size & 5 \\
\hline & $\begin{array}{l}\text { Shift to company job, crop farming, sheep } \\
\text { and goat farming }\end{array}$ & 5 \\
\hline \multirow{5}{*}{ Greatest challenge during strict and partial lockdown phases } & Lower milk price & 36 \\
\hline & Higher feed cost & 24 \\
\hline & Don't know & 17 \\
\hline & Difficulty selling milk & 14 \\
\hline & $\begin{array}{l}\text { Higher management costs (veterinary } \\
\text { care, labour, transport) }\end{array}$ & 9 \\
\hline
\end{tabular}

\section{Discussion}

The pandemic caused by the novel SARS-CoV-2 (COVID-19) virus has put enormous pressure on global health systems, economies, and social life. Such effects were also noted for the 2018 pandemic influenza in the United States of America. To handle the mild influenza pandemic situation, the total cost was US dollars 374 billion, to handle severe influenza pandemics US dollars 7.3 trillion; the 2003 SARS outbreak in East and Southeast Asia led to losses of US dollars 12-28 billion [8]. Yet, also at the individual level, economic losses due to pandemic situations can be severe: in April 2020, dairy farmers were forced to dump 4 million gallons of milk in the United States of America [43], and in Nepal, damage to dairy products was about US dollars 17 million [44]. Additionally, the daily losses to the Indian dairy sector during the strict lockdown time were about US dollars 9 million. Such economic losses indicated that the investigation into the impacts of COVID-19 on small-scale dairy farming level [28] should be carried out.

The COVID-19 pandemic severely affected dairy farmers in Bengaluru, in terms of their regular access to cattle feed on their own and public land, dairy herd size, milk production, marketing, and longer-term dairy management strategies. First, the lockdown impacted the feeding strategies of dairy producers: the availability of green forage decreased because dairy producers were scared of COVID-19 and obliged to the strict movement restrictions imposed across the city, which impeded the collection of fodder from lakes and public spaces. Likewise, availability of dry forage shrank significantly due to transportation restrictions; being a generally important resource during the dry season [45], finger millet 
gained even greater importance during the lockdown because of the lower availability of other feeds, which increased its price [33]. The price of commercial concentrate feeds was also rising due to the impacts of COVID-19 on feed value chains [8,33]. Similar impacts of the lockdown on feed availability and price were also reported from the United States of America [46], Pakistan [47], China [46], and Ethiopia [48]. Globally, for dairy production, disruptions in feed supply were reported for soybean meal, wheat bran, oil cake, and hay [49].

The second severe problem for Bengaluru's dairy farmers was decreased milk demand after lockdown implementation. On the one hand, consumers purchased less milk due to movement restrictions [28]; on the other hand, the shutdown of trade, industries, government services, and educational institutions and their canteens and catering services further decreased the demand for milk and milk products [46]. Given the lower demand for milk, Indian dairy plants collected and processed less milk and reduced the price paid to milk producers by 35-40\% on average [33]. Similarly, in neighbouring Bangladesh, the milk price declined by 17\% due to COVID-19 [23]. Further milk price declines were reported from Pakistan [47], Canada [18], and the United States of America [46,50]. Consequently, milk dumping by farmers was reported from Canada and the United States of America [51,52] and even in Indian farmers were discarding milk in the absence of procurement [33]. In Kenya, by contrast, the milk price did not decrease because the dairy cooperatives supported their dairy producers by paying the same price as before the lockdown [49]. As a reaction to the declining milk price, dairy herd sizes in Bengaluru decreased, mainly on medium and large farms, because dairy producers sold dairy cows as a mitigation strategy. In consequence, the average milk yield per farm decreased, but the daily milk yield per cow was not affected. A decline in daily milk yield per cow was reported from Pakistan due to lower feed input [47], and for Bangladesh, a reduction of cows' daily milk yield by 2.6 to 3.3 L was estimated [23]. In Kenya, the national milk yield declined due to normal seasonal variation, but herd size did not change because selling cows was difficult for farmers during lockdown with closed markets, and the milk price stayed at the pre-lockdown level [49].

Overall, milk marketing problems in Bengaluru were more severe at the start of the first lockdown. Later on, farmers implemented lockdown mitigation strategies for their dairy herd management, and dairy cooperatives published a COVID-19 hygiene protocol on a notice board for dairy production and milk delivery, in addition to the city authorities' hygiene protocol for the general population. Farmers started to utilise existing financial and labour resources within their families and bank loans to carry on dairy farming. The American small dairy farmers were given financial support under the Paycheck Protection Program to overcome the COVID-19 crisis [46,50]. Similarly the World Bank had previously sanctioned grants and loans for Ebola responses to rebuild health, agriculture, and social safety nets [53].

Taken together, our farmers' responses point to a decrease in farm revenues due to lower milk production per farm, lower milk price, higher feed costs, less feed availability, and higher cost of services related to dairy farming, such as veterinary care. Similarly, Uddin et al. [23] estimated a decline in daily farm revenues ranging from 1.9 to 4.7 US dollars per farm for dairy producers in Bangladesh. In Bengaluru, the majority of the interviewed farmers did not have clear ideas on how to mitigate the shock. Only a few claimed that having stored feed and reduced herd size before lockdown would have helped mitigate the shock. Moreover, about two-thirds of the farmers stated that the reduced milk price and higher feed costs were the main obstacles to overcoming the shock, and the use of additional resources could only partially mitigate it. Dairy producers' strategy to engage in informal or formal jobs and/or intensify and diversify agricultural activities such as crop cultivation and small ruminant rearing were also reported from different sources [54]. However, lower milk production per farm diminished not only farmers' dairy revenues but also the farming household's own milk consumption, potentially threatening the nutritional status, especially of vulnerable members $[55,56]$. 
In India, dairy cooperatives and private processors reduced milk collection and processing drastically because of the lower demand for processed products with short shelf-life, e.g., ice cream or curd (yoghurt) [33]. To mitigate the milk market shock, dairy cooperatives and related companies could have processed the extra milk into products with longer shelf-life, such as butter, ghee (clarified butter), skimmed, or powdered milk [57]. A few processing units reported a higher demand during lockdown for paneer (fresh cheese; shelflife between 3 to 21 days), often used in Indian dishes [58]. Processing of extra milk into products with a longer shelf-life was constrained by processing capacity [59], however, and the lack of storage facilities [60]. The selling of processed dairy products, often bought by convenience, is also constrained by the strong preference of Indian consumers for fresh milk, which is then bought directly from dairy producers and processed at home [61]. Harvesting of added value through processing by dairy producers themselves might thus be a limited mitigation strategy to milk market shock. To mitigate limited feed availability, dairy cooperatives and other institutions could train farmers in feed conservation practices and support communal infrastructure for drying, ensiling, and storing forages [62]. A shock management fund or disaster management insurance might be another option to support farmers in case of drought, flood, pandemics, and other calamities [63]. The advantages of such a fund can be seen regarding the support the Mongolian livestock sector receives during extremely cold winters [64] or of general insurance schemes in support of Indian crops and livestock $[16,65]$.

\section{Conclusions}

The analysis of dairy farmers' problems with and reaction to the COVID-19 lockdown imposed in Bengaluru demonstrates that these farmers were willing and able to maintain their daily activity in the midst of a severe crisis and thus continued to supply fresh milk to consumers in and around the megacity. We found that, following the lockdown, the share of farmers feeding concentrates decreased while those feeding dry forages increased significantly. Milk yield dropped in all surveyed farms as dairy farmers sold lactating cows to cope with higher prices for inputs as well as the unavailability of feed during lockdown. In addition, lower milk prices, especially at dairy cooperatives, became a crucial problem for dairy farmers. However, the role of the dairy cooperatives, which are very important in India, could have been more proactive and, in addition to the elaboration of sound milk-hygiene concept, could have advised farmers on forages conservation and processed surplus milk into products with longer shelf-life. Furthermore, setting up shock mitigation funds or offering insurance to their members are policies to be explored with a view to better coping with future calamities.

Author Contributions: Conceptualization, M.S.A. and E.S.; methodology, M.S.A. and M.R.; investigation and field data curation, M.S.A.; data analysis, M.S.A. and M.R.; visualization, M.S.A.; writing —original draft preparation, M.S.A.; writing—review and editing, M.R.; supervision funding acquisition, E.S. All authors have read and agreed to the published version of the manuscript.

Funding: The authors gratefully acknowledge the financial support provided by the German Research Foundation (DFG) through grant number SCHL 587/6-2 as part of the Research Unit FOR2432/2.

Institutional Review Board Statement: Not applicable.

Informed Consent Statement: All interviewees participating in this study were fully informed about the study purpose and were assured that their information would be treated anonymously. Therefore, only persons giving explicit informed oral consent were interviewed.

Data Availability Statement: For scientific purposes, data can be made available to individual scientists upon written request to the first author.

Acknowledgments: We deeply thank all dairy producers and their families for their time. We thank our research assistants for their commitment and diligent survey work. We thank our scientific partners at the National Institute of Animal Nutrition and Physiology (NIANP) for their valuable collaboration and the University of Agricultural Sciences Bangalore (UASB, GKVK campus) for their 
logistic support during research work. M.S.A. thanks the Department of Dairy and Poultry Science, Hajee Mohammad Danesh Science and Technology University, Dinajpur, Bangladesh for his current PhD study leave.

Conflicts of Interest: The authors declare no conflict of interest.

\section{Appendix A}

Table A1. Description of variables used to understand the impacts of COVID-19 lockdown on small-scale dairy farmers in Greater Bengaluru, India.

\begin{tabular}{|c|c|}
\hline Variables & Description \\
\hline \multicolumn{2}{|l|}{ Socio-economic of the household } \\
\hline Household size & Total number of household members \\
\hline $\begin{array}{l}\text { Head of household: age, gender, marital status, } \\
\text { education, emplovment }\end{array}$ & Characteristics of the household head \\
\hline Importance of dairy as an income for the household & $\begin{array}{l}\text { Dairy production is the only income/Dairy production is the main } \\
\text { income amongst others/Dairy production is a complementary } \\
\text { income/Dairy production is not an income/Don't know or prefer not } \\
\text { to answer }\end{array}$ \\
\hline \multicolumn{2}{|l|}{ Dairy herd } \\
\hline Lactating cow & Number of cows currently milked \\
\hline Dry cow & Number of cows currently dry \\
\hline Heifer & Number of heifers, defined as pregnant or already inseminated once \\
\hline \multicolumn{2}{|r|}{ 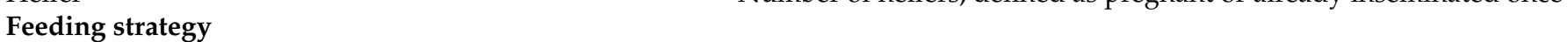 } \\
\hline Concentrate & Supply of concentrate per day and animal, in kilograms \\
\hline Green forage & Supply of green forages per day and animal, in kilograms \\
\hline Dry forage & Supply of dry forage per day and animal, in kilograms \\
\hline Cutting grass & Supply of grass cut from lake shores per day and animal, in kilograms \\
\hline Grazing & Daily grazing on the lake shores, in hours \\
\hline Public land & Use of other public grounds, e.g. road side areas, for grazing (yes/no) \\
\hline Own land-Grazing & Use of own farm land for grazing (yes/no) \\
\hline Own land-Cultivation & Use of own farm land for cultivating forages (yes/no) \\
\hline \multicolumn{2}{|l|}{ Milk production and marketing } \\
\hline Milk production & Milk production per day and animal, in liter \\
\hline Milk price & Milk price per liter, in Indian rupee \\
\hline Milk marketing & $\begin{array}{l}\text { Marketing channels used to sell milk, e.g. dairy } \\
\text { cooperative/neighbours/middleman }\end{array}$ \\
\hline \multicolumn{2}{|l|}{ Challenges due to COVID-19 lockdown } \\
\hline Challenges & Greatest challenges during COVID-19 lockdown (open question) \\
\hline Feeding strategy & $\begin{array}{l}\text { Change in feeding strategy (decrease/increase of each type of } \\
\text { feedstuff) and reasons }\end{array}$ \\
\hline Herd's in-and outflow & $\begin{array}{l}\text { Number of dairy cattle born/bought/sold/dead since the first } \\
\text { lockdown and reasons }\end{array}$ \\
\hline Milk production & Change in milk production (decrease/increase) and reasons \\
\hline Shock mitigation & Strategies for shock mitigation in the coming months (open question) \\
\hline
\end{tabular}

\section{References}

1. Nagendra, H.; Bai, X.; Brondizio, E.S.; Lwasa, S. The urban south and the predicament of global sustainability. Nat. Sustain. 2018, 1, 341-349. [CrossRef]

2. Arha, A.; Audichya, R.; Pant, D.C. Challenges in the Urban and Peri-urban Transition Zones and Strategies for Sustainable Cities: Experiences from Selected Cities. In The Security of Water, Food, Energy and Liveability of Cities; Maheshwari, B., Purohit, R., Malano, H., Singh, V.P., Amerasinghe, P., Eds.; Springer Science+Business Media: Dordrecht, Germany, 2014; pp. 71-85.

3. Liu, X.; Xu, Y.; Engel, B.A.; Sun, S.; Zhao, X.; Wu, P.; Wang, Y. The impact of urbanization and aging on food security in developing countries: The view from Northwest China. J. Clean. Prod. 2021, 292, 126067. [CrossRef]

4. Shi, K.; Chen, Y.; Yu, B.; Xu, T.; Li, L.; Huang, C.; Liu, R.; Chen, Z.; Wu, J. Urban expansion and agricultural land loss in China: A multiscale perspective. Sustainability 2016, 8, 790. [CrossRef]

5. Hussain, H.; Hanisch, M. Dynamics of peri-urban agricultural development and farmers' adaptive behaviour in the emerging megacity of Hyderabad, India. J. Environ. Plan. Manag. 2014, 57, 495-515. [CrossRef] 
6. Rosenzweig, C.; Iglesias, A.; Yang, X.B.; Epstein, P.R.; Chivian, E. Implications for food production, plant diseases, and pests. Glob. Chang. Hum. Health 2001, 2, 90-104. [CrossRef]

7. Wheeler, T.; Braun, J.V. Climate Change Impacts on Global Food Security. Science 2013, 341, 508-513. [CrossRef]

8. Qiu, W.; Rutherford, S.; Mao, A.; Chu, C. The Pandemic and its Impacts. Health Cult. Soc. 2017, 9, 3-11. [CrossRef]

9. Snacken, R.; Kendal, A.P.; Haaheim, L.R.; Wood, J.M. The Next Influenza Pandemic: Lessons from Hong Kong, 1997. Emerg. Infect. Dis. 1999, 5, 195-203. [CrossRef]

10. Ifediora, O.F.; Aning, K. West Africa's ebola pandemic: Toward effective multilateral responses to health crises. Glob. Gov. 2021, 23, 225-244. [CrossRef]

11. Ingram, A. Outbreak, epidemic, pandemic: The politics of global health events. A review of Sara E. Davies' Containing Contagion. Singap. J. Trop. Geogr. 2021, 42, 350-352. [CrossRef]

12. WHO. Comparative Analysis of National Pandemic Influenza Preparedness Plans; World Health Organization: Geneva, Switzerland, 2011.

13. Kumar, P.; Singh, S.S.; Pandey, A.K.; Singh, R.K.; Srivastava, P.K.; Kumar, M.; Dubey, S.K.; Sah, U.; Nandan, R.; Singh, S.K.; et al. Multi-level impacts of the COVID-19 lockdown on agricultural systems in India: The case of Uttar Pradesh. Agric. Syst. 2021, 187, 103027. [CrossRef]

14. Zhang, Y.; Jiang, B.; Yuan, J.; Tao, Y. The impact of social distancing and epicenter lockdown on the COVID-19 epidemic in mainland China: A data-driven SEIQR model study. medRxiv 2020. medRxiv:20031187. [CrossRef]

15. Worldometer Reported Cases and Deaths by Country or Territory. Available online: https://www.worldometers.info/ coronavirus / (accessed on 10 May 2021).

16. Singh, A.; Kumar, P.; Kumar, H.; Neeraj, A.; Kumar, P.; Kour, G. Status of Livestock Insurance in India and A Complete Guide: An Evidence-Based Review. Int. J. Livest. Res. 2020, 10, 8-19. [CrossRef]

17. Marshall, A. Why Farmers Are Dumping Milk, Even as People Go Hungry. WIRED 2020, 23 April 2020. Available online: https:/ / www.wired.com/story /why-farmers-dumping-milk-people-hungry/ (accessed on 27 May 2021).

18. BBC Coronavirus: Why Canada Dairy Farmers Are Dumping Milk. BBC NEWS 2020, 6 April 2020. Available online: https: / / www.bbc.com/news/world-us-canada-52192190 (accessed on 28 June 2021).

19. Shashidhar, A. Coronavirus Impact: Dairy Industry Faces 30\% Dip in Demand. Business Today (Corporate, Story) 2020, 8 April 2020. Available online: https://www.businesstoday.in/current/corporate/coronavirus-impact-dairy-industry-faces-30--dip-indemand/story /400517.html\%0A (accessed on 13 May 2021).

20. Drury, C. Coronavirus: Dairy Farmers Throwing Thousands of Litres of Milk Away as Demand Dries Up in Lockdown. Independent Health 2020, 9 April 2020. Available online: https:/ / www.independent.co.uk/news/health/coronavirus-dairy-milk-farmersthrow-away-shortage-lockdown-a9457001.html (accessed on 20 May 2021).

21. Mutua, F.; Kang'ethe, E.; Grace, D. The COVID-19 pandemic and its implications for food safety in East Africa. ILRI Discuss. Paper 2021, 40, 1-18.

22. Azevedo, D. Dairy Prices on a Roller Coaster in Brazil Due to Pandemic. Dairy Global 2020, 30 April 2020. Available online: https: / www.dairyglobal.net/Market-trends / Articles/2020/4/Dairy-prices-on-a-roller-coaster-in-Brazil-due-to-pandemic577264E/ (accessed on 30 June 2021).

23. Uddin, M.M.; Akter, A.; Khaleduzzaman, A.B.M.; Sultana, M.N.; Hemme, T. Application of the Farm Simulation Model approach on economic loss estimation due to Coronavirus (COVID-19) in Bangladesh dairy farms-strategies, options, and way forward. Trop. Anim. Health Prod. 2021, 53, 33. [CrossRef]

24. Vorotnikov, V. COVID-19: Iran's Dairy Industry in the Spotlight. Dairy Global 2020, 29 April 2020. Available online: https: //www.dairyglobal.net/industry-and-markets/market-trends/covid-19-irans-dairy-industry-in-the-spotlight/ (accessed on 19 May 2021).

25. NDDB Share of Agriculture \& Livestock Sector in GDP. National Dairy Development Board. 2021. Available online: https: //www.nddb.coop/information/stats/GDPcontrib (accessed on 5 December 2021).

26. DAHD Annual Report 2019-2020. In Department of Animal Husbandry and Dairying. Ministry of Fisheries, Animal Husbandry and Dairying; Government of India: New Delhi, India, 2020.

27. Biswal, J.; Vijayalakshmy, K.; Rahman, H. Impact of COVID-19 and associated lockdown on livestock and poultry sectors in India. Vet. World 2020, 13, 1928-1933. [CrossRef]

28. Chandel, B.S.; Dixit, A.K.; Singh, A.; Devi, A. Economic Analysis of the Impact of COVID-19 Lockdown on Indian Dairy Sector. Agric. Situat. India 2020, 21-27.

29. Mishra, A.; Bruno, E.; Zilberman, D. Compound natural and human disasters: Managing drought and COVID-19 to sustain global agriculture and food sectors. Sci. Total Environ. 2021, 754, 142210. [CrossRef]

30. WEO Tentative Stabilization, Sluggish Recovery? World Economic Outlook Report. Available online: https://www.imf.org/en/ Publications/WEO/Issues/2020/01/20/weo-update-january2020 (accessed on 12 May 2021).

31. Hussain, S. India's COVID-19 Crisis Has Placed Its Dairy Farmers at a Crossroads. Wire 2020, 6 August 2020. Available online: https://thewire.in/agriculture/india-covid-19-dairy-farmers-milk-production (accessed on 25 May 2021).

32. Parida, Y.; Misra, H. Budget 2020: FM recognised dairy, livestock segment's critical role in economy. Financial Express 2020, 6 February 2020. Available online: https: / / www.financialexpress.com/budget/budget-2020-fm-recognised-dairy-livestocksegments-critical-role-in-economy/1857823/ / (accessed on 10 May 2021).

33. Bhandari, G.; Ravishankar, K.M. Implications of COVID-19 for Indian Dairy Sector. Food Sci. Rep. 2020, 1, 43-46. 
34. Prasad, C.S.; Anandan, S.; Gowda, N.K.S.; Schlecht, E.; Buerkert, A. Managing nutrient flows in Indian urban and peri-urban livestock systems. Nutr. Cycl. Agroecosyst. 2019, 115, 159-172. [CrossRef]

35. Reichenbach, M.; Pinto, A.; König, S.; Bhatta, R.; Schlecht, E. Dairy production in an urbanizing environment-Typology and linkages in the megacity of Bengaluru, India. PLoS ONE 2021, 16, 0255791. [CrossRef] [PubMed]

36. Pinto, A.; Yin, T.; Reichenbach, M.; Bhatta, R.; Schlecht, E.; König, S. Phenotypic dairy cattle trait expressions in dependency of social-ecological characteristics along rural-urban gradients. Sustainability 2020, 12, 9021. [CrossRef]

37. Kumar, P.; Geneletti, D.; Nagendra, H. Spatial assessment of climate change vulnerability at city scale: A study in Bangalore, India. Land Use Policy 2016, 58, 514-532. [CrossRef]

38. Guhathakurta, P.; Khedikar, S.; Menon, P.; Prasad, A.K.; Sable, S.T.; Advani, S.C. Observed Rainfall Variability and Changes over Karnataka State; India Meteorological Department, Ministry of Earth Sciences, Government of India: New Delhi, India, 2020.

39. WWO World Weather Online Database. Bangalore Monthly Climate Averages. Available online: https://www.worldweatheronline. com/bangalore-weather-averages/karnataka/in.aspx (accessed on 13 January 2021).

40. Chandrasekar, G.K.; Satyanarayan, K.; Jagadeeswary, V.; Shree, J.S. Relationship between Socio-Economic and Psychological Factors of Dairy Farmers with Days Open-A Study in Rural Karnataka. Int. J. Pure Appl. Biosci. 2017, 5, $171-177$.

41. Dairying in Karnataka, A Statistical Profile 2015; National Dairy Development Board: Anand, India, 2015.

42. Line, B. Karnataka Covid lockdown: Inter-State, Inter-District Vehicle Movement Only on Emergency. Business Line, 27 April 2021. Available online: https:/ / www.thehindubusinessline.com/news/national/karnataka-covid-lockdown-inter-state-inter-districtvehicle-movement-only-on-emergency/article34420133.ece (accessed on 12 May 2021).

43. Newman, J.; Bunge, J. Farmers dump milk, break eggs as Coronavirus restaurant closings destroy demand. The Wall Street Journal, 9 April 2020. Available online: https:/ / www.wsj.com/articles/farmers-deal-with-glut-of-food-as-coronavirus-closesrestaurants-11586439722 (accessed on 12 May 2021).

44. NepaliSansar COVID-19 inflicts NPR 2 Bn loss on Nepal dairy industry! NepaliSansar, 15 April 2020. Available online: https: //www.nepalisansar.com/business/ covid-19-inflicts-npr-2-bn-loss-on-nepal-dairy-industry/ (accessed on 12 May 2021).

45. Reichenbach, M.; Pinto, A.; Malik, P.K.; Bhatta, R.; König, S.; Schlecht, E. Dairy feed efficiency and urbanization-A system approach in the rural-urban interface of Bengaluru, India. Livest. Sci. 2021, 253, 104718. [CrossRef]

46. Wang, Q.; Liu, C.Q.; Zhao, Y.F.; Kitsos, A.; Cannella, M.; Wang, S.K.; Han, L. Impacts of the COVID-19 pandemic on the dairy industry: Lessons from China and the United States and policy implications. J. Integr. Agric. 2020, 19, 2903-2915. [CrossRef]

47. Hussain, S.; Hussain, A.; Ho, J.; Sparagano, O.A.E.; Zia, U.-R. Economic and Social Impacts of COVID-19 on Animal Welfare and Dairy Husbandry in Central Punjab, Pakistan. Front. Vet. Sci. 2020, 7, 1-5. [CrossRef]

48. Tesfaye, A.; Habte, Y.; Minten, B. COVID-19 is shifting consumption and disrupting dairy value chains in Ethiopia. In COVID-19 and Global Food Security; International Food Policy Research Institute: Washington, DC, USA, 2020; pp. 42-45.

49. Odhong, C.; Wassie, S.; Dijk, S.V.; Wilkes, A. The Impact of COVID-19 on Low-Emission Dairy Development in Kenya Findings from a Rapid Scoping Study; CGIAR Research Program on Climate Change, Agriculture and Food Security, Wageningen University and Research: Wageningen, The Netherlands, 2020.

50. Mulvey, C.; Peters, R.; Rutkowski, N. Impacts of COVID-19 on the US Dairy Industry; Worcester Polytechnic Institute: Worcester, MA, USA, 2020.

51. Weersink, A.; von Massow, M.; McDougall, B. Economic thoughts on the potential implications of COVID-19 on the Canadian dairy and poultry sectors. Can. J. Agric. Econ. 2020, 68, 195-200. [CrossRef]

52. Khan, N.; Fahad, S.; Naushad, M.; Faisal, S. COVID-2019 locked down impact on dairy industry in the world. SSRN Electron. J. 2020, 8-15. [CrossRef]

53. Gostin, L.O.; Friedman, E.A. A retrospective and prospective analysis of the West African Ebola virus disease epidemic: Robust national health systems at the foundation and an empowered WHO at the apex. Lancet. 2015, 385, 1902-1909. [CrossRef]

54. Gupta, V. How COVID-19 Has Put Punjab's Dairy Farmers in a Tight Spot. Money Control, 9 December 2020. Available online: https:/ / www.moneycontrol.com/news/business/how-covid-19-has-put-punjabs-dairy-farmers-in-a-tight-spot-6208 741.html (accessed on 20 May 2021).

55. Dror, D.K.; Allen, L.H. The importance of milk and other animal-source foods for children in low-income countries. Food Nutr. Bull. 2011, 32, 227-243. [CrossRef] [PubMed]

56. Brzeska, J.; Das, M.; Fan, S. Social protection for poor, vulnerable and disadvantaged groups. China Agric. Econ. Rev. 2015, 7, 668-687. [CrossRef]

57. Provost, J.; Rosero, G.; Brümmer, B.; Schlecht, E. To sell, not to sell, or to quit: Exploring milk producers' approaches after a supply chain disruption in Northwest Cameroon. World Dev. 2022, 150, 105709. [CrossRef]

58. Garg, L.; Kumar, K. Dairy sector in pre, during COVID-19 and post pandemic periods: A review. Pharma Innov. 2021, 10, 621-625. [CrossRef]

59. Kumar, F.R.; Thamila, M. Dairy cooperative developments in India-An Overview. Asia Pac. J. Res. 2015, 1, 137-141.

60. Cariappa, A.A.; Acharya, K.K.; Adhav, C.A.; Sendhil, R.; Ramasundaram, P. COVID-19 induced lockdown effects on agricultural commodity prices and consumer behaviour in India-Implications for food loss and waste management. Socioecon. Plann. Sci. 2021, 1-23. [CrossRef] 
61. Lapar, M.L.A.; Choubey, M.; Patwari, P.; Kumar, A.; Baltenweck, I.; Jabbar, M.A.; Staal, S. Consumer preferences for attributes of raw and powdered milk in Assam, Northeast India. In Demand for LivestockProducts in Developing Countries with a Focus on Quality and Safety Attributes: Evidence from Asia and Africa; ILRI (ILCA and ILRAD): Addis Ababa, Ethiopia, 2010; pp. $103-115$.

62. Singh, O. Conservation and utilization of grassland resources for sustainable livestock production in different agro-climatic zones of India. In The International Grassland Congress Proceedings, Nairobi, Kenya, 25-29 October 2021; University of Kentucky: Lexington, KY, USA, 2021.

63. Francesco, F.; Zewdie, Y. ILRI Launches New Drought Index Insurance for Resilience in the Sahel and Horn of Africa Project. Available online: https:/ / www.ilri.org/news/ilri-launches-new-drought-index-insurance-resilience-sahel-and-horn-africaproject (accessed on 19 August 2021).

64. The World Bank. New Insurance Model Protects Mongolian Herders from Losses. Available online: https://www.worldbank.org/ en/news/feature/2015/03/04/new-insurance-model-protects-mongolian-herders-from-losses (accessed on 20 August 2021).

65. Aditya, K.S.; Khan, T.; Kishore, A. Adoption of crop insurance and impact: Insights from India. Agric. Econ. Res. Rev. 2018, 31, 163-174. [CrossRef] 